\author{
ANETA RAYZACHER-MAJEWSKA \\ UKSW WARSZAWA \\ ORCID 0000-0003-2540-0273
}

\title{
ZADANIA KATECHEZY W DYREKTORIACH Z LAT 1971-2020
}

„Omne agens agit propter finem” - wszystko, co działa, działa dla celu. Stwierdzenie to można odnieść również do katechezy i jej podmiotów. Nie ulega bowiem wątpliwości, iż katecheza jest działaniem celowym. Wskazuje się więc „punkt dojścia, rezultaty, jakie pragnie się osiągnąć za pośrednictwem katechezy”. Za papieżem Janem Pawłem II można stwierdzić, iż „ostatecznym celem katechezy jest doprowadzić kogoś nie tylko do spotkania z Jezusem Chrystusem, ale do zjednoczenia, a nawet głębokiej z Nim zażyłości”"2. Jest to jednak cel na tyle ogólny, iż bez wskazań pośrednich, przybliżających do jego realizacji, z jednej strony trudno byłoby zaplanować konkretne działanie, z drugiej zaś - zweryfikować, jaką drogę ku owemu celowi już przebyto. Potrzebna jest zatem jeszcze jedna kategoria - zadania katechezy, które zostaną omówione w niniejszym artykule. Głównym celem będzie zaprezentowanie rozwoju myśli katechetycznej na temat zadań katechezy w ogólnych dyrektoriach katechetycznych z lat 1971, 1997 i 2020 oraz polskim Dyrektorium katechetycznym z 2001 roku. Na kanwie tej refleksji zostanie również ukazany związek zadań katechezy z praktyką katechetyczną. Źródłami dla tego artykułu będą wskazane dokumenty katechetyczne, przeanalizowane i omówione w kontekście literatury przedmiotu.

W ogólnym rozumieniu zadaniem jest „to, co należy wykonać”3. Jest to zatem pewna czynność obowiązkowa do wykonania, służąca realizacji określonego celu. E. Alberich zauważa, iż „czasami cele są, niesłusznie, porównywane do zadań katechezy, jako że te ostatnie wskazują raczej na działania lub operacje, jakie katecheza winna spełnić w perspektywie osiągnięcia zamierzonych celów" ". Należy zatem odróżniać zadania od celu, a w ich wzajemnej relacji uznać podporządkowanie zadań celowi. Ks. F. Kamecki mówiąc o zadaniach w kontekście celu określa je

\footnotetext{
1 E. Alberich, Cele katechezy, w: J. Gevaert, K. Misiaszek (red.), Słownik katechetyczny, Warszawa 2007, s. 128.

2 CT 5.

3 Słownik języka polskiego, https://sjp.pwn.pl/sjp/zadanie;2542078.html [18.08.2021].

$4 \quad$ E. Alberich, Cele katechezy..., s. 128.
} 
mianem „upraktycznienia”, „konkretyzacji”. Twierdził, iż właśnie w zadaniach cel katechezy jest lepiej widoczny. Z kolei ks. J. Charytański wyjaśniał, iż zadania są rozpatrywane bardziej ze strony katechizującego, zaś cele - od strony katechizowanego ${ }^{5}$. Ilekroć dziś jest mowa o zadaniach katechezy, na gruncie katechetycznym pod tym pojęciem najczęściej rozumie się sześć głównych kierunków działania określonych w Dyrektorium ogólnym o katechizacji (85-86), poprzez które realizuje się nadrzędny cel. Warto jednak zauważyć, iż samo ich określenie pojawiło się już w Ogólnej instrukcji katechetycznej w 1971 roku i właśnie tam zostały one opisane.

\section{Ogólna instrukcja katechetyczna}

Odkąd podczas II Soboru Watykańskiego zapowiedziano wydanie dokumentu w całości poświęconego katechezie, dokument ten był wyczekiwany w kręgach katechetycznych. Skoro więc ukazała się Ogólna instrukcja katechetyczna (directorium catechisticum generale - DCG), poddano analizie jej treść, szukając w niej inspiracji dla działalności katechetycznej. Taką inspiracją niewątpliwie mogła się stać refleksja na temat zadań katechezy, czy też - mówiąc precyzyjniej - zadania posługi słowa i zadań katechezy. „Posługa słowa winna być dobrze świadoma powierzonego sobie zadania, które zmierza do obudzenia żywej wiary, a więc zwracającej umysł ku Bogu, skłaniającej do posłuszeństwa wiary w Jego działaniu, prowadzącej do żywego poznania mowy tradycji, wypowiadającej i ujawniającej prawdziwy sens świata i ludzkiej egzystencji"6. W tak nakreślonym zadaniu posługi słowa widoczne są różne obszary życia ludzkiego, które należy kształtować w ramach katechezy. Niezależnie jednak od tego ogólnego wskazania, w kolejnych numerach dokumentu bardziej szczegółowo omówiono zadania katechezy. Ich realizacja miała wspomagać wzrastanie w wierze zarówno całej wspólnoty, jak i poszczególnych wiernych. Zgodnie z tym zamysłem, zadania katechezy sformułowane w DCG odnosiły się do wszystkich obszarów życia ludzkiego, naznaczając je nową jakością wynikającą z komunii z Bogiem, której wyrazem była relacja człowieka do siebie samego i innych ludzi.

Pierwszym z zadań katechezy wynikającym z DCG jest otwieranie na laskę Bożą - „przygotowanie ludzi na przyjęcie działania Ducha Świętego i stałe nawracanie się"7. Takie zadanie ściśle wiąże się z tym, iż wiara jest darem Bożym. Darem, o który człowiek winien zabiegać, a który z chwilą przekazania niesie konkretne zobowiązanie. Obdarowany nie tylko z uwagą słucha tego, co Bóg do niego mówi, ale także winien zechcieć kształtować swe życie według Bożych nakazów. Realizacji

\footnotetext{
Zob. F. Kamecki, Ważniejsze zadania katechetyczne, „Katecheta” 4(1982), s. 145; J. Charytański, Z Dobra Nowina w szkole, Warszawa 1991, s. 58.

6 DCG 16.

7 DCG 22.
} 
tego zadania sprzyja m.in. osoba katechety, który głoszoną naukę jednocześnie potwierdzi własnym świadectwem życia (zresztą nie bez racji czasem zadania katechezy utożsamiane są z zadaniami katechety ${ }^{8}$ ). Najpełniej zaś dokonuje się to przez modlitwę.

Z otwieraniem na łaskę Bożą łączy się drugie zadanie katechezy, które można określić jako uzdalnianie do chrześcijańskiego świadectwa. Katecheza ma wspomagać w nawiązaniu wspólnoty z Bogiem i ukazywać orędzie jako zabezpieczenie najwyższych wartości ludzkiego życia ${ }^{9}$. Zjednoczenie z Bogiem ma swoje potwierdzenie $\mathrm{w}$ relacjach międzyludzkich, kształtowanych zgodnie $\mathrm{z}$ wolą Bożą i rozpoznanym powołaniem. Autorzy dokumentu omawiając to zadanie, piszą wprost o pełnieniu obowiązków wiary, bowiem istotnie wiara nakłada obowiązki tak względem Boga, jak i względem ludzi. Katecheza stanowi pomoc w rozpoznawaniu tych obowiązków i ukazuje możliwość ich realizacji stosownie do możliwości danej osoby. Obowiązek należy przy tym rozumieć nie jako konieczność zrobienia czegoś, wynikającą z nakazu, ale sposób postępowania zabezpieczający najwyższe wartości życia ludzkiego. Rola egzystencjalnej interpretacji orędzia podejmowana w ramach katechezy jest więc kluczowa dla takiego postrzegania obowiązków wiary. Swoistym papierkiem lakmusowym katechezy będzie wzrost cnoty miłości we wspólnotach i w życiu poszczególnych katechizowanych.

Innym zadaniem katechezy jest poznawanie wiary. Nie kwestionując potrzeby i znaczenia praktyk religijnych, zwrócono uwagę na konieczność zgłębiania zbawczych Bożych tajemnic, dokonujących się w życiu ludzkim. Dowartościowano przy tym potrzebę właściwego rozumienia źródeł nauczania - Pisma Świętego i Tradycji1 ${ }^{10}$. Mimo zwięzłości numeru omawiającego tę kwestię, należy z pełną powagą potraktować wezwanie do stopniowego rozumienia prawdy o Bożym planie. Należy przy tym podkreślić, iż choć w zadaniu mowa jest o „poznawaniu” wiary, to nie chodzi jedynie o przekaz wiedzy, utrwalanie wiadomości. Przeciwnie - zbawcze wydarzenia przedstawiane katechizowanym mają być odbierane przez nich jako znaczące dla ich życia. Nie ma zatem żadnej sprzeczności w takim ujęciu poznawania wiary z twierdzeniem ks. F. Blachnickiego, który podkreślał, iż „celem katechezy nie jest przekazanie wiedzy, ale to co zamierzał osiągnąć katechumenat: poddania życia dziecka pod panowanie Boga, urzeczywistnienie w nim królestwa Bożego"11.

Kolejne zadanie przedstawione w DCG jest złożone - dotyczy bowiem zarówno pomocy w czynnym, świadomym i dostojnym uczestniczeniu w liturgii, jak i wychowania do rozważania Słowa Bożego i modlitwy prywatnej. Można

\footnotetext{
8 Zob. R. Chałupniak, Katechetyka fundamentalna, w: R. Chałupniak, J. Kostorz, Wybrane zagadnienia z katechetyki, Opole 2002, s. 48.

9 Zob. DCG 23.

10 Zob. DCG 24.

11 F. Blachnicki, Katechetyka fundamentalna, Lublin 1970, s. 81.
} 
więc je określić hasłem: wychowanie do modlitwy liturgicznej i prywatnej ${ }^{12}$. Ważne jest przy tym łączne traktowanie obu wymiarów omawianego zadania. Z jednej bowiem strony wspólnota chrześcijańska wzrasta w wierze, uczestnicząc w liturgii i nabożeństwach, dlatego tak istotną rolę odgrywa przygotowanie do udziału w liturgii. Przygotowanie, które nie będzie ograniczało się do wyjaśnienia obrzędów, ale wychowywało wiernych wewnętrznie „do modlitwy, dziękczynienia, czynienia pokuty, odmawiania modlitw z ufnością, do ducha wspólnoty, właściwego zrozumienia symboliki”"13. W ten sposób będą oni prawdziwie przeżywać liturgię. Jednocześnie zadaniem katechezy jest wychowanie do rozważania słowa Bożego i modlitwy prywatnej. Poza modlitwą wspólnotową ważne jest, by każdy mógł nawiązać i pogłębiać osobistą relację z Bogiem i nieustannie modlił się, niezależnie od położenia, w jakim się znajdzie.

Ważnym zadaniem potwierdzającym, iż katecheza nie może być oderwana od życia, a sprawy katechizowanych domagają się uwzględnienia w przekazie, jest chrześcijańskie naświetlenie ludzkiej egzystencji ${ }^{14}$. Postulowana w tym punkcie chrześcijańska interpretacja spraw ludzkich pozostaje w związku ze wspomnianym wcześniej świadectwem. Umiejętność odczytania we własnej sytuacji Bożego wezwania skutkuje przyjmowaniem postawy inspirowanej Ewangelią, co z kolei przyczynia się do wzrostu miłości u poszczególnych wiernych i w kościelnych wspólnotach. Takie odniesienie do ludzkiego życia wyraźnie potwierdza element antropologiczny, na co zwracał uwagę ks. J. Charytański twierdząc, iż „tak mocne podkreślenie elementu ludzkiego, antropologicznego, w głoszeniu słowa Bożego wydaje się być niejako oficjalnym uznaniem zasad współczesnej [nam] fazy rozwoju ruchu katechetycznego, zwanej katechezą antropologiczną, egzystencjalną czy też katechezą interpretacji"15.

Wyraźnym wskazaniem płynącym z Ogólnej instrukcji katechetycznej jest budowanie właściwych relacji nie tylko wewnątrz wspólnot katolickich, ale także względem innych, czego dowodzi kolejne zadanie katechezy - pomoc w dialogu ekumenicznym ${ }^{16}$. Realizacja tego zadania miała polegać na jasnym wykładaniu pełnej nauki Kościoła oraz zaznajamianiu się z innymi wyznaniami, by katechizowani mieli świadomość tego, co łączy, jak i tego, co dzieli. Nie zabrakło również wskazania do tego, jak przekazywać tę naukę - „zarówno z miłością, jak i odpowiednią stanowczością"17. Odnośnie do jedności chrześcijan, Ogólna instrukcja katechetyczna przekazywała wytyczne zawarte w dotychczasowych dokumentach, zwłaszcza soborowych.

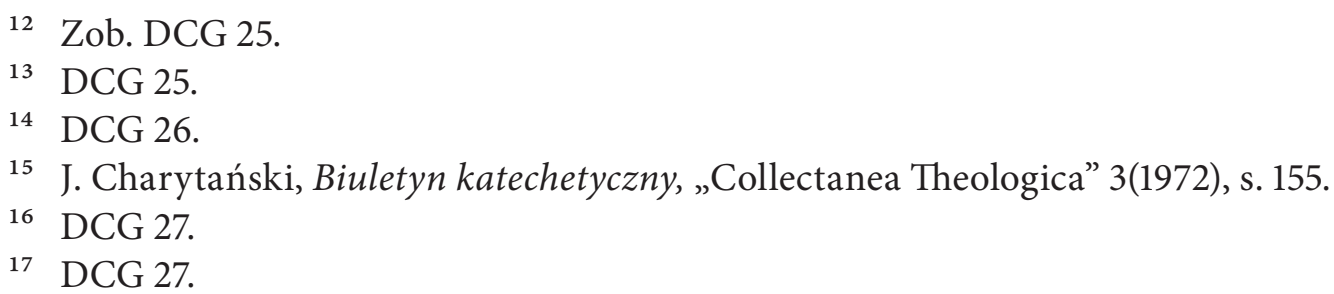


W kwestii dialogu, tym razem jednak podejmowanego z ludźmi i kulturami niechrześcijańskimi, Ogólna instrukcja katechetyczna prezentuje kolejne zadanie, którym jest realizacja misji Kościoła w świecie ${ }^{18}$. Warunkiem wypełnienia tego zadania jest dojrzałość $\mathrm{w}$ wierze - w przeciwnym razie trudno by było podejmować dialog, bez silnego fundamentu własnych przekonań. W ramach tego zadania zakłada się także szerzenie światła Ewangelii, zatem współpracę w dziele misyjnym, które spoczywa na wszystkich ochrzczonych. Rolę katechezy w kształtowaniu umiejętności dialogu z innymi wskazywał także kard. J. Wright $w$ referacie podczas Międzynarodowego Kongresu Katechetycznego w Rzymie (20-25.09.1971), potwierdzając tym samym zbieżność treści opracowanego dokumentu katechetycznego $\mathrm{z}$ ówczesnymi orientacjami na gruncie katechetyki ${ }^{19}$.

Wreszcie zadaniem katechezy w świetle DCG było również kierowanie myśli i pragnień ku nadziei eschatologicznej ${ }^{20}$. Takie ukształtowanie wiernych wpisywałoby się w dojrzałość i ugruntowanie w wierze. Zadanie to również należy rozumieć dwuwymiarowo - $\mathrm{z}$ jednej strony nadzieja katechizowanych ma być kierowana na dobra przyszłe, które mają stać się ich udziałem, z drugiej zaś rzeczywistość ziemska - relacje międzyludzkie winny być tak kształtowane, bo owo ziemskie życie dawało przedsmak życia wiecznego. Skutkiem takiego postępowania byłoby udoskonalenie społeczności ludzkiej. To już kolejne zadanie zmierzające ku poprawie relacji społecznych poprzez katechezę, zatem ukazujące jej ścisły związek z życiem i przełożenie głoszonych treści na praktykę.

Przełożenie treści katechetycznych na praktykę życia pojawia się także w wyjaśnieniu kolejnego - ostatniego - zadania katechezy wg DCG. Zadaniem tym jest pomoc w zapoczątkowaniu i rozwoju wiary ${ }^{21}$. Wiara jest rzeczywistością dynamiczną - zależy nade wszystko od łaski, ale także od modlitwy i odpowiedzi człowieka na otrzymaną łaskę. Owa dynamika wiąże się także ze zróżnicowaniem adresatów katechezy - zależnie do wieku katechizowanych, różny będzie stopień zrozumienia słowa Bożego i umiejętność zastosowania go we własnym życiu. Katecheza towarzysząc człowiekowi na każdym etapie jego życia winna przyczyniać się do tego, by coraz pełniej pojmował przekazywane treści i kształtował według nich swoje postępowanie.

Kolejny numer Ogólnej instrukcji katechetycznej zawiera swoiste podsumowanie rozważań na temat zadań katechezy. Zwraca się tam uwagę na konieczność wiązania katechezy z innymi zadaniami duszpasterskimi. Pojęcie „zadan” pojawia się w tym punkcie w nieco innym znaczeniu - tego, co w świetle adhortacji apostolskiej Jana Pawła II Catechesi tradendae zwykło określać się mianem funkcji

18 DCG 28.

19 Zob. J. Charytański, Biuletyn katechetyczny, „Collectanea Theologica” 3(1972), s. 140.

20 Zob. DCG 29.

21 DCG 30. 
katechezy - wtajemniczenie, kształcenie i wychowanie ${ }^{22}$. Jednocześnie autorzy DCG podkreślają, iż ,jest rzeczą niezmiernie ważną, by katecheza skupiła w sobie wspomniane wyżej aspekty, ale w ten sposób, żeby nie oddzielać jednego aspektu od pozostałych, ze szkodą dla nich"23. Zadania katechezy odnoszą się do różnych obszarów życia chrześcijańskiego, mają też odzwierciedlenie zarówno w życiu wspólnoty, jak i pojedynczych wiernych.

Choć w refleksji katechetycznej podejmowanej po 1971 roku pojawiała się kwestia zadań katechezy, to trudno stwierdzić, by kategoria ta miała odnosić się do zadań w takim ujęciu i brzmieniu, jak zaproponowano je w Ogólnej instrukcji katechetycznej. Wielowymiarowość tych zadań z pewnością pozwoliłaby powiązać z nimi treść artykułów, jednak wydaje się, iż zadania katechezy wg DCG nie zaistniały jako zwarty katalog działań, ku którym zmierza katecheta, by jego uczniowie mogli osiągnąć ostateczny cel katechezy. Już dwa lata po ogłoszeniu DCG Barbara Jabłońska na łamach „Katechety” opisywała szczególne zadania katechezy ${ }^{24}$. Z tekstu jednak bardziej wyłaniają się nie tyle zadania, ile założenia katechezy - szczególnie dla roku wprowadzającego do pełnego udziału we Mszy świętej. Literalnie nie ma tam nawiązań do zadań katechezy z DCG - nawet można stwierdzić, iż prowadzona przez autorkę krytyka nauczania religii ograniczonego do podawania treści niewiele ma wspólnego z poznawaniem wiary w rozumieniu DCG.

Powiązania z numerami 21-31 DCG brakuje również w innym artykule - Zadania $k a t e c h e z y^{25}$ o. Benedykta Stefana Zimy. Autor skupił się raczej na prezentacji cech katechety oraz wskazówek metodycznych odnośnie do tego, jak należy katechizować. Jedynym elementem treściowo wiążącym się z zadaniami katechezy, jednak bez nawiązywania autora do DCG, jest podkreślenie konieczności wiązania treści katechez z życiem, stanowiącego odpowiedź na pytanie: jak odpowiem Bogu? Podobne cele przyświecają autorowi innego artykułu z zadaniami katechezy w tytule - ks. H. Łuczak odnosząc się do narastających trudności w katechetycznej posłudze słowa adresowanej do młodzieży formułuje kilka postulatów, które mogłyby odmienić obserwowaną sytuację. Nie pojawia się zaś literalnie żadne z zadań katechezy w takim brzmieniu, w jakim zostały one przedstawione w DCG. Brak wierności literze zadań nie oznacza jednak braku wierności ich duchowi. Przejaw tego stanowią choćby postulaty powiązania przekazu z życiem, uwzględnienie

\footnotetext{
22 Zob. DCG 31. W adhortacji funkcje te wyprowadzane są z próby definicji katechezy, jakiej podjął się papież: „Ogólnie mówiąc, katecheza jest wychowaniem w wierze dzieci, młodzieży i dorosłych, a obejmuje przede wszystkim nauczanie doktryny chrześcijańskiej, przekazywane na ogół w sposób systematyczny i całościowy, dla wprowadzenia wierzących w pełnię życia chrześcijańskiego" (CT 18). Funkcja wychowawcza bierze się z tego, iż katecheza jest wychowaniem; funkcja dydaktyczna, kształcąca - ze względu na podejmowane w ramach katechezy nauczanie doktryny; z kolei wtajemniczenie chrześcijańskie równoznaczne jest $\mathrm{z}$ wprowadzeniem w pełnię życia sakramentalnego.

23 DCG 31.

24 B. Jabłońska, Szczególne zadania katechezy, „Katecheta” 3(1973), s. 110-112.

25 B.S. Zima, Zadania katechezy, „Katecheta” 3(1976), s. 127-129.
} 
życia sakramentalnego, czynnej realizacji przykazania miłości ${ }^{26}$. Kolejny raz więc termin „zadania katechezy” został użyty w innym znaczeniu niż w Ogólnej instrukcji katechetycznej.

Pojęcie zadań katechezy zawarł w swej refleksji prezentowanej na łamach „Katechety” również ks. F. Kamecki ${ }^{27}$. Autor precyzuje jednak w podtytule, iż będzie to refleksja po przeczytaniu adhortacji Jana Pawła II Familiaris consortio, dlatego skupi się na zadaniach rodzinnych katechezy. We wstępie jednak zauważa, iż zadań katechetycznych przybywa, a „każdy dokument Kościoła w ostatnim dwudziestoleciu, począwszy od II Soboru Watykańskiego, dopisuje katechezie nowe zadania, konkretyzuje jej ogólny cel. Tych zadań jest wiele. Można je pogrupować schematycznie w następujące: zadania doktrynalne, biblijne, liturgiczne, eklezjalne, moralne, egzystencjalne, kulturowe, społeczne, krytyczne wobec świata i systemów myślowych czy ideowych, polityczne itp. ${ }^{28}$. Choć z tego wyliczenia bez problemu można wybrać określenia zadań katechezy pasujące do tych, które nakreślono w DCG, to wydaje się, iż klasyfikacja zaproponowana przez ks. F. Kameckiego formułuje zadania zbyt ogólnie. Tak mało konkretne kategorie zadań nie pomogą $\mathrm{w}$ realizacji nadrzędnego celu katechezy, zanim nie zostaną doprecyzowane. Tymczasem zadania katechezy w ujęciu DCG charakteryzował ten stopień konkretności, który łatwiej było przełożyć na konkretne dążenia katechety i osiągnięcia katechizowanego.

Zdecydowanie lepsze rozumienie zadań katechezy wg Ogólnej instrukcji katechetycznej można odnaleźć w refleksji ks. J. Charytańskiego. Można to wiązać z zaangażowaniem ks. Charytańskiego w opiniowanie projektu DCG oraz jego udziałem w oficjalnej polskiej delegacji Komisji Episkopatu ds. Katechizacji na Międzynarodowym Kongresie Katechetycznym w Rzymie w 1971 roku. W swoich artykułach porządkuje on posoborową refleksję katechetyczną, a wręcz czyni bardziej oczywistym związek zadań katechezy wg DCG z dokumentami II Soboru Watykańskiego. Zarówno bowiem cel katechizacji (misja słowa, misje kultyczne, misja królewska), jak i jej przedmiot (Pismo Święte, liturgia - sakramenty i rok liturgiczny, czytania i życie chrześcijańskie) oraz metoda (głoszenie słowa Bożego, osobowe spotkanie z Bogiem, poszukiwanie właściwych ujęć i rozwiązań oraz duch wspólnoty $)^{29}$ omówione przez niego na bazie dokumentów soborowych mają swe przełożenie na zadania katechezy w DCG. Kiedy więc ks. J. Charytański na początku lat 90. prezentował integralność celów katechezy, to zaprezentowana przez

\footnotetext{
26 H. Łuczak, Katecheta wobec zadań katechezy w Polsce, „Katecheta” 6(1981), s. 264.

27 F. Kamecki, Ważniejsze zadania katechetyczne, „Katecheta” 4(1982), s. 145-151.

28 Tamże, s. 145.

29 Zob. J. Charytański, Inspiracje soborowe w katechetyce, w: W. Kubik (red.), Katecheza po Soborze Watykańskim II, Warszawa 1985, t. 1, s. 15-37. Do samych zadań katechezy autor odnosi się w innym tekście. Zob. J. Charytański, Katecheza w świetle Ogólnej instrukcji katechetycznej (Directorium catechisticum generale), w: Katecheza po Soborze..., s. 45-52.
} 
niego myśl w sposób oczywisty była wzbogacona treściami adhortacji Catechesi tradendae, jednak miała też swe odniesienie do zadań katechezy wg DCG (potrzeba socjalizacji - również kościelnej, wychowanie do wolności, kształtowanie postaw, zdobywanie zdolności operatywnych - odkrywanie światła dla ludzkich problemów i umiejętności odpowiedzi na nie; umiejętność dialogu, umiejętności związane z życiem liturgicznym ${ }^{30}$ ).

\section{Dyrektorium ogólne o katechizacji}

O ile zadania katechezy wg DCG nie znalazły należytego odzwierciedlenia w refleksji katechetycznej, o tyle analogiczna kwestia przedstawiona w Dyrektorium ogólnym o katechizacji z 1997 roku na dobre zagościła w teorii i praktyce. Nowy dokument miał kształtować katechezę Kościoła katolickiego przez kolejne niemal ćwierć wieku. Refleksję nad zadaniami katechezy w DOK poprzedza wyjaśnienie, iż - tak jak to miało miejsce w DCG, tak i w omawianym dokumencie - odróżniano cel katechezy od jej zadań. Zarysowano przy tym ich wzajemną relację podkreślając, iż cel realizuje się przez zadania, które zostały zaczerpnięte od Jedynego Nauczyciela - Jezusa Chrystusa ${ }^{31}$. Jak nauczanie Jezusa znane z kart Ewangelii obejmuje wszystkie wymiary życia chrześcijańskiego, tak i zadania katechezy wynikające z DOK odpowiadają tym wymiarom. Wiara ma być znana, celebrowana, przeżywana i wyrażana w modlitwie, a wszystko to dokonuje się we wspólnocie chrześcijańskiej, której zadaniem jest głoszenie Chrystusa aż po krańce ziemi. Z tak dynamicznie pojmowaną wiarą wiąże się sześć zadań katechezy: rozwijanie poznania wiary, wychowanie liturgiczne, formacja moralna, nauczanie modlitwy, wychowanie do życia wspólnotowego i wprowadzenie do misjii ${ }^{32}$. Wyliczając je warto podkreślić, iż cztery pierwsze zadania zawarte są w numerze 85. i otrzymały miano „podstawowych”. Jednocześnie jednak nie ma podstaw do tego, by pozostałe dwa uznawać za mniej istotne, skoro w nagłówku numeru 86. zapowiedziano „inne podstawowe zadania katechezy". Warto również zauważyć, iż rozwijanie poznania wiary, wychowanie liturgiczne, formacja moralna i nauczanie modlitwy przywodzą na myśl strukturę Katechizmu Kościoła Katolickiego - wyznanie wiary, celebrację chrześcijańskiego misterium, życie w Chrystusie oraz modlitwę chrześcijańską. To tradycyjny schemat katechetyczny. Zważywszy na fakt, iż wyznanie wiary poprzedzone jest poznaniem historii zbawienia wraz z jej trzema etapami (Stary Testamentem, życiem Jezusa i historią Kościoła), zadania katechezy współbrzmią z siedmioma kolumnami katechezy - podstawowymi elementami kształtującymi ją.

\footnotetext{
30 Zob. J. Charytański, Z Dobrą Nowinq...., s. 58-62.

31 Zob. DOK 84.

32 DOK 85-86.
} 
Rozwijanie poznania wiary jest zadaniem na pozór związanym $\mathrm{z}$ realizacją dydaktycznej funkcji katechezy. Takie ujęcie byłoby jednak zawężeniem, bowiem wprawdzie chodzi o to, by pogłębiać znajomość Bożego Objawienia, jednak Dobra Nowina o zbawieniu jako orędzie wiary, nadziei i miłości przyczynia się chęci spotkania z Jezusem i trwania w komunii z Nim, co z kolei wpływa na życie kształtowane według Jego nauki. Poznawane treści mają zatem prowadzić do wyznania wiary, rozumianego nie tylko jako deklaracja składana podczas Mszy świętej, ale jako codzienne wyrażanie tej wiary swoimi wyborami i postępowaniem, po którym będzie można rozpoznać w katechizowanym ucznia Jezusa. Jak bowiem zauważają autorzy DOK, „pogłębienie w poznaniu wiary oświeca po chrześcijańsku życie ludzkie, umacnia życie wiary oraz uzdalnia do uzasadnienia jej w świecie"33. Zadanie to ma swoje przełożenie na wychowanie do prawdy i szacunek do prawd wiary - zwłaszcza, jeśli będzie należycie prowadzone, czyli katechizowani będą prowadzeni do stopniowego odkrywania całej prawdy o Bożym planie względem człowieka $^{34}$.

Wychowanie liturgiczne jako zadanie katechezy nie jest zwykłym instruktażem czy pouczeniem o tym, jak należy zachować się w czasie celebracji. Ze względu na zbawczą obecność Jezusa w sakramentach, uczestnictwo w nich musi być pełne, świadome i czynne ${ }^{35}$. Przygotowanie do takiego uczestnictwa dokonuje się w ramach katechezy, a jego zakres jest znacznie szerszy niż ukazanie znaczenia liturgii i sakramentów. Jak przystało na wychowanie, zadanie to ma prowadzić do pożądanych zmian $w$ funkcjonowaniu wychowanka. W tym wypadku chodzi o kształtowanie takich postaw, poprzez które katechizowani będą mogli odpowiedzieć Bogu, zwracając się do Niego w modlitwie stosownie do aktualnych potrzeb - z wdzięcznością, prośbą czy przebłaganiem. Ważnym aspektem wychowania liturgicznego jest również kształtowanie ducha wspólnoty, skoro spotkanie z Jezusem dokonuje się właśnie we wspólnocie. „Z jednej strony chodzi o pomoc w nawiązaniu osobowego kontaktu z Chrystusem, a nawet o doprowadzenie katechizowanego do głębokiej z Nim zażyłości. Z drugiej zaś strony w katechezie inicjacyjnej bardzo wyraźnie zakreślony jest aspekt społeczny chrześcijańskiego wychowania: wprowadzenie w życie wspólnoty Kościoła, uczenie odpowiedzialności za nią, za jej rozwój w świecie zgodny z planem Bożym"36. Innym istotnym zagadnieniem związanym z tym zadaniem jest prowadzenie do właściwego rozumienia symboliki.

\footnotetext{
${ }^{33}$ DOK 85.

34 Zob. S. Dziekoński, Zadania współczesnej katechezy w dokumentach katechetycznych Kościoła $w$ Polsce, w: S. Dziekoński (red.), Przesłanie dokumentów katechetycznych Kościoła w Polsce, Warszawa 2003, s. 104 (103-122); Z. Marek, Zbawcze orędzie w posłudze katechetycznej, w: Katecheza w świetle Dyrektorium ogólnego o katechizacji, Kraków 1999, s. 98.

${ }^{35}$ DOK 85.

36 S. Dziekoński, Zadania współczesnej katechezy..., s. 106.
} 
Formacja moralna jako zadanie katechezy jest konsekwencją pójścia za Chrystusem. Katecheza powinna więc uczyć, co to znaczy iść za Jezusem - a jako że jest wychowaniem w wierze, a wychowanie nieodłącznie wiąże się z kształtowaniem postaw - ma też przekazywać uczniom postawy Nauczyciela ${ }^{37}$. Autorzy Dyrektorium omawiając to zadanie zwracają uwagę na słowo głoszone i słowo

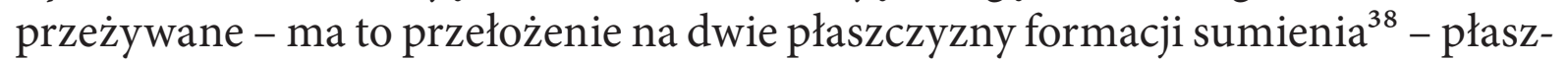
czyznę intelektualną oraz płaszczyznę wolitywno-emocjonalną. Sama znajomość zasad moralnych i wymagań nie wystarczy, by były one przestrzegane. Dopiero odkrycie ich jako dobrych i służących dobru oraz decyzja o ich przestrzeganiu sprawią, iż dana postawa nie tylko będzie znana, ale także przyjmowana. Jeśli zaś chodzi o konkretne wytyczne dla tego zadania, to „Kazanie na Górze, w którym Jezus podejmuje na nowo dekalog i wyciska na nim ducha błogosławieństw, jest nieodzownym punktem odniesienia dla formacji moralnej ${ }^{39}$. Katechizowany za sprawą katechetycznej posługi słowa winien być przygotowany do składania moralnego świadectwa, czyli postępowania inspirowanego Ewangelią.

Inną konsekwencją podążania za Jezusem jest postawa modlitewna i kontemplacyjna, jaką posiadał Chrystus. Wiąże się z nią kolejne zadanie katechezy - nauczanie modlitwy ${ }^{40}$. W relacji z Jezusem nie może zabraknąć kontaktu z Nim i zwracania się do Boga tak, jak tego uczy Jezus Chrystus. Dopiero wtedy związek z Bogiem będzie żywy i osobisty, gdy nie zabraknie w nim adoracji, uwielbienia, dziękczynienia, zaufania, prośby czy też podziwu dla Jego chwały ${ }^{41}$. Realizacja tego zadania będzie więc polegała na kształtowaniu w katechizowanych uczuć, z jakimi Jezus zwracał się do Ojca, dlatego wzorem wszelkiej modlitwy jest Modlitwa Pańska. Wprawdzie w określeniu tego zadania pojawia się termin „nauczanie”, co może sugerować pamięciowe przyswojenie formuł modlitewnych czy analizę ich treści. W DOK podkreślono jednak, iż katecheza ma być przeniknięta klimatem modlitwy - nie można więc poprzestawać na formułach i ich znajomości, ale ich odmawianiu winno towarzyszyć przekonanie o Bożej obecności - Jego bliskości, przyjaźni i trosce. $Z$ tego względu zadanie winno być realizowane od najmłodszych lat, bowiem wtedy znacznie łatwiej jest kształtować tę ufność wobec Boga jako Ojca.

Ponieważ katecheza ma uzdalniać do czynnego uczestniczenia w życiu i posłaniu Kościoła, kolejnym zadaniem katechezy jest wychowanie do życia wspólnotowego $^{42}$. Aby faktycznie owo życie we wspólnocie było prowadzone, należy solidnie do niego przygotować. Wychowanie to opiera się na kształtowaniu konkretnych postaw, inspirowanych nauczaniem i postępowaniem Jezusa. Są to duch prostoty

\footnotetext{
37 Zob. DOK 85.

38 Zob. Z. Marek, Zbawcze orędzie..., s. 100; S. Dziekoński, Zadania współczesnej katechezy..., s. 109.

39 DOK 85.

40 Zob. DOK 85.

${ }^{41}$ Zob. tamże; zob. także: Z. Marek, Zbawcze orędzie..., s. 101.

42 Zob. DOK 86.
} 
i pokory, troska o najmniejszych, zwracanie uwagi na tych, którzy się oddalili, upomnienie braterskie, wspólna modlitwa, wzajemne przebaczenie oraz łącząca te wszystkie postawy miłość braterska ${ }^{43}$. W odniesieniu do tego zadania podkreśla się, iż dotyczy ono zarówno wspólnoty Kościoła, jak i wszystkich innych wspólnot, do których katechizowany należy lub będzie należeć. Jednocześnie warto mieć świadomość, iż wspólnoty naturalne, których uczeń jest członkiem, przygotowują do funkcjonowania we wspólnocie wierzących. $Z$ tego względu realizacja zadania może i powinna odbywać się począwszy od najmłodszych grup wiekowych. Dzieci mając doświadczenia własnych rodzin bądź grup przedszkolnych czy innych rówieśniczych, poprzez liczne odniesienia mogą przygotowywać się do świadomego funkcjonowania we wspólnocie nadprzyrodzonej, do której należą od chwili chrztu. Z wychowaniem do życia wspólnotowego wiąże się także troska o wymiar ekumeniczny i braterskie postawy względem innych Kościołów i wspólnot chrześcijańskich. Konkretne wskazania to tego przytoczono za Ogólna instrukcją katechetyczna - w realizacji tego zadania należy dbać o jasny wykład doktryny, unikając wszelkich błędnych interpretacji, a także zapewnić dobrą znajomość innych wyznań, by lepiej rozpoznawać w nich to, co wspólne od tego, co różni. Nade wszystko zaś katecheza winna wzbudzać i ożywiać pragnienie prawdziwej jedności.

Istotnym dopowiedzeniem odnośnie do zadań katechezy w DOK są niektóre rozważania ich całości. Podkreśla się w nich, iż wszystkie zadania są potrzebne, każde z nich na swój sposób realizuje cel katechezy, zadania nakładają się na siebie i wspólnie rozwijają. Zwrócono także uwagę na dwa wielkie środki służące realizacji zadań - przekazywanie orędzia ewangelicznego oraz doświadczenie życia chrześcijańskiego. Choćby z tego względu nie da się w prosty sposób przypisać zadań funkcjom katechezy - w odniesieniu do każdego $\mathrm{z}$ nich potrzebny jest element treściowy oraz nawiązanie do życia. Autorzy DOK zachęcają również do rozpatrywania zadań katechezy w kategorii daru - wówczas zadanie przestaje być jedynie nakazem czy powinnością, a staje się odpowiedzią na uprzednio otrzymany dar. Nie bez znaczenia są w tym numerze DOK liczne odniesienia do Ogólnej instrukcji katechetycznej - w dokumencie z 1997 roku wyraźnie wybrzmiewa konieczność zakorzeniania wiary - tak całości, jak i każdego jej wymiaru - w doświadczeniu życiowym. Po upływie ponad 25 lat dowartościowanie ludzkiej egzystencji $\mathrm{w}$ procesie katechetycznym stało się nie tylko orientacją czy propozycją, ale wręcz wymaganiem.

${ }^{43}$ Zob. tamże. 


\section{Dyrektorium katechetyczne Kościoła katolickiego w Polsce}

Dyrektorium ogólne o katechizacji - stosownie do charakteru tego dokumentu domagało się implementacji na grunt Kościołów w poszczególnych krajach. Recepcję założeń zawartych w DOK podjęto w warunkach polskich, czego owocem było Dyrektorium katechetyczne Kościoła katolickiego w Polsce, zatwierdzone podczas 313. zebrania plenarnego Konferencji Episkopatu Polski w Łowiczu 20 czerwca 2001 roku. Zadania katechezy zostały omówione w tym dokumencie w części pierwszej, poświęconej katechezie w posłudze duszpasterskiej Kościoła, w rozdziale dotyczącym natury katechezy. Refleksja nad zadaniami zawiera się w numerach 23-30. Poza numerem wprowadzającym (23) oraz omówieniem kolejno każdego z zadań (24-29), dokonano także swoistego podsumowania, stanowiącego jednocześnie wskazanie do ich realizacji w praktyce katechetycznej (30). Już w pierwszym ze wskazanych numerów zauważa się, iż „cele katechezy osiągane są poprzez realizację zadań, jakie stawia i wysuwa się odpowiedzialnym za katechezę" ${ }^{44}$. Utożsamiono więc zadania katechezy z zadaniami katechety - tak jak sugerował to ks. J. Charytański ${ }^{45}$. Polskie dyrektorium katechetyczne wiernie odzwierciedla refleksję nad zadaniami katechezy zawartą w DOK. Nowością i istotą krajowego dokumentu jest wskazanie pilnych kwestii związanych z tymi zadaniami w polskich realiach, z uwzględnieniem specyfiki działalności katechetycznej w Polsce.

Odnośnie do rozwijania poznania wiary, autorzy PDK podkreślają związek zadania $\mathrm{z}$ wychowaniem do prawdy, a także jego rolę w przeciwstawianiu się stereotypowi scjentystycznemu. Realizacja zadania spoczywa zarówno na szkolnych lekcjach religii, jak i katechezie parafialnej ${ }^{46}$, w ramach której również obecne są pewne elementy nauczania. Zadanie to jawi się jako szczególnie pilne w polskich warunkach, bowiem brak znajomości prawd wiary diagnozowany jest jako jeden $\mathrm{z}$ głównych powodów kruchości i zaniku wiary. Widać $\mathrm{w}$ tym wyzwanie zarówno dla katechetów, jak i osób i instytucji odpowiedzialnych za ich formację. Konieczne jest zrozumienie znaczenia pogłębionego przygotowania intelektualnego katechetów - w niczym nie zagraża to postawom religijnym czy świadectwu, więc niezrozumiałe jest przeciwstawianie ich sobie. Ma to dość często miejsce w kontekście dyskusji na temat katechezy i szkolnego nauczania religii. Zarzuca się czasem niektórym, iż chcieliby zredukować lekcje religii do samego przekazu wiedzy. Tymczasem nie chodzi o jakiekolwiek redukcjonistyczne podejście, które w każdej wersji jest niewłaściwe, ale należytą troskę o oba skrzydła, na których unosi się duch ludzki ku kontemplacji prawdy - wiarę i rozum ${ }^{47}$.

\footnotetext{
44 PDK 23.

45 J. Charytański, Z Dobra Nowina w szkole, Warszawa 1991, s. 58.

46 Zob. PDK 24.

${ }^{47}$ Zob. FR, Wstęp.
} 
Wychowanie liturgiczne w polskim dyrektorium katechetycznym ukazane jest jako zadanie domagające się współdziałania katechezy rodzinnej, nauczania religii $\mathrm{w}$ szkole i katechetycznych form duszpasterstwa parafialnego ${ }^{48}$. Wynika to $z$ konieczności łączenia wyjaśnień dotyczących tajemnic wiary i sposobów ich celebrowania z udziałem w liturgii, który również ma swe katechetyczne znaczenie. Potrzeba zaangażowania wszystkich środowisk katechetycznych, spośród których inspirująca rola przypisywana jest parafii, wynika $z$ faktu, iż wychowanie liturgiczne odnosi się zarówno do przygotowania i przyjmowania sakramentów, jak również do przeżywania roku liturgicznego. Brak zrozumienia tego zadania przez którekolwiek ze środowisk będzie utrudniać jego realizację, co jest widoczne choćby na przykładzie niektórych rodzin uczestniczących w katechezie przygotowującej dzieci do pełnego udziału w Eucharystii. Aby tego uniknąć, należy podejmować wychowanie liturgiczne $\mathrm{w}$ ramach różnych form katechezy i w odniesieniu do wszystkich odbiorców. W katechezie dorosłych będzie ono realizowane poprzez homilię, przygotowanie do sakramentu małżeństwa oraz katechezę dla rodziców i chrzestnych przed chrztem dzieci. Z kolei katecheza dzieci i młodzieży na każdym swoim etapie winna mieć charakter ściśle liturgiczny, co szczególnie uwidacznia się w związku z przygotowaniem do sakramentów.

$\mathrm{W}$ odniesieniu do formacji moralnej w polskim dokumencie powtórzono za Dyrektorium ogólnym o katechizacji, iż zadanie polega głównie na formacji sumienia, przy czym dodano, iż współcześnie sumienie człowieka wielokrotnie wystawiane jest na próbę ${ }^{49}$. Innym istotnym wskazaniem jest konieczność uwzględnienia w realizacji zadania elementu tak nadprzyrodzonego, jak i naturalnego - podkreśla się bowiem, że formacja ta ma pogłębiać formację ludzką - stąd tak ważna jest współpraca środowisk, a nade wszystko spójność ideałów wychowawczych i wartości. Co do tych ostatnich podkreśla się, że „ideału wychowawczego w formacji ludzkiej chrześcijanina nie można obniżać do poziomu miernego i przeciętne-

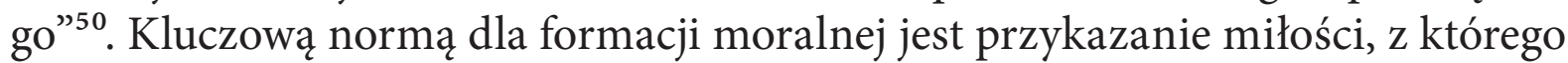
realizacją katechizowany spotyka się wpierw na gruncie rodziny, dlatego tak bardzo podkreśla się rolę katechezy rodzinnej jako fundamentalnej dla wychowania moralnego, jednocześnie podkreślając znaczenie katechezy młodzieży na etapie szkół ponadpodstawowych, bowiem to właśnie ci uczniowie wkrótce podejmą swe dorosłe role $\mathrm{w} \dot{z} y \mathrm{ciu}^{51}$, w tym również role małżeńskie.

Autorzy polskiego Dyrektorium zwracają uwagę na szczególne trudności związane z realizacją kolejnego zadania katechezy - nauczania modlitwy, które jednak w krajowym dokumencie określone jest mianem „wychowania do modlitwy”. W związku z zanikiem praktyki modlitwy w wielu domach, katechizowani nie

48 Zob. PDK 25.

49 Zob. PDK 26.

50 PDK 26.

51 Zob. PDK 26; S. Dziekoński, Zadania współczesnej katechezy..., s.112. 
rozumieją sensu modlitwy i nie odczuwają jej potrzeby ${ }^{52}$. Wychowanie do modlitwy należy więc poszerzyć o rozbudzenie życia modlitwy przez ukazanie jej sensu. Praktyka katechetyczna związana z tym zadaniem winna polegać na jednoczesnym nauczaniu modlitwy i wdrażaniu do jej praktykowania. W rodzinach chrześcijańskich jest to powinnością rodziców, którzy nie zawsze jednak wywiązują się ze swych katechetycznych zobowiązań. Znacznie częściej obarcza się tym szkolne nauczanie religii, które winno wprowadzać w praktykę wspólnej modlitwy, przekazywać wiedzę na temat modlitwy oraz ukazywać jej sens. Nie zastąpi jednak doświadczenia modlitwy we wspólnocie wiary, jaką jest choćby wspólnota parafialna, dlatego na niej również spoczywają konkretne obowiązki odnośnie do omawianego zadania katechezy. Katecheza parafialna oraz grupy modlitewne odgrywają kluczową rolę we wtajemniczaniu w modlitwę wspólnoty Kościoła. Nie można też pomijać pozytywnych form pobożności ludowej, strzegąc jednak, by tam, gdzie to konieczne, zostały poddane oczyszczeniu czy poprawie.

Polskie Dyrektorium katechetyczne nadaje specyficzny rys także kolejnemu zadaniu katechezy - wychowaniu do życia wspólnotowego. Podkreśla rolę wspólnot naturalnych - rodziny i narodu, które w polskiej tradycji istotnie splatały swe dzieje z życiem Kościoła. Stąd tak ważna jest rola katechezy w umacnianiu więzi rodzinnych i szacunku dla każdego z jej członków - zwłaszcza w perspektywie wyraźnych ataków na rodzinę i jej przedstawicieli - zwłaszcza tych nienarodzonych czy seniorów. Z kolei w odniesieniu do Ojczyzny, katecheza winna przekazywać prawdę o historii narodu, a także prezentować katolicką naukę społeczną, według której wierzący winni kształtować relacje społeczne w rożnych dziedzinach ${ }^{53}$. Mimo doniosłości wychowania do życia we wspólnotach naturalnych, katecheza nie może pomijać przygotowania do życia we wspólnocie Kościoła. Zróżnicowaniu wspólnot, do życia w których uczniowie są wychowywani, zdaje się odpowiadać wielość form katechetycznej posługi słowa. Wychowanie do życia wspólnotowego winno dokonywać się zarówno w rodzinie - reprezentującej zarówno społeczność naturalną, jak i zakorzenioną w Kościele, czy zwanej wręcz Kościołem domowym i drogą Kościoła ${ }^{54}$. Z realizacji tego zadania nie może zwalniać się również szkoła, w której poza przekazem wiary należy ukazywać prawdziwy obraz Kościoła i pogłębiać poczucie przynależności do wspólnoty wierzących. Wreszcie nie może zabraknąć troski Kościoła - wspólnoty parafialnej, która poprzez duszpasterstwo katechetyczne dopełnia szkolne nauczanie religii. Katecheza w parafii umożliwia też przeżywanie przynależności do Kościoła.

Również wprowadzenie do misji zostało ukazane w polskim dyrektorium katechetycznym jako zadanie, którego realizacja w równym stopniu spoczywa na rodzinie, parafii i szkole. Zadanie to rozumiane jako pełnienie misji chrześcijanina

\footnotetext{
52 Zob. PDK 27.

${ }^{53}$ Zob. PDK 28.

54 Zob. tamże.
} 
w świecie, zobowiązuje do składania świadectwa. Już w 2001 roku zauważano, iż „szczególna odpowiedzialność spoczywa na wierzących za nową ewangelizację, która winna być podjęta w większą intensywnością również przez Kościół w Polsce" ${ }^{\text {55 }}$. Obecnie potrzeba ta jest jeszcze bardziej wyraźna - zwłaszcza, iż w wielu przypadkach rodziny przestały być środowiskami, w których obserwuje się świadectwo wiary. Nie oznacza to jednak potrzeby działalności misyjnej w Polsce, choć czasem słyszy się tego typu sugestie. Fakt, iż w niektórych środowiskach potrzebna jest nowa ewangelizacja, nie przekreśla konieczności katechezy, która adresowana jest do osób wierzących. Pewną formą pośrednią jest szkolne nauczanie religii, w których uczniowie uczestniczą po wyrażeniu takiej woli przez rodziców. Szkolne lekcje domagają się silnego ukierunkowania ewangelizacyjnego. To zróżnicowanie sytuacji odbiorców nie zmienia niczego we współpracy misyjnej, która wciąż pozostaje obowiązkiem ochrzczonych. Wprowadzenie do misji poza uzdalnianiem do składania świadectwa oznacza także uświadamianie zobowiązań misyjnych i przygotowanie do ich realizacji. Rozumienie tego zadania jest znacząco wspierane przez szkolne lekcje religii, w ramach których warto odnosić się do wiedzy z innych przedmiotów i przekazywać „informacje o potrzebach misyjnych Kościoła, przybliżać sylwetki misjonarzy i podejmowaną przez nich działalność w krajach misyjnych"56. Przykłady patronów misji - św. Teresy od Dzieciątka Jezus i bł. Marii Teresy Ledóchowskiej - dowodzą, jaką rolę odgrywa rodzina w realizacji tego zadania. Wreszcie z jego realizacji nie może czuć się zwolniona parafia - to właśnie ona jest wezwana do modlitwy, ofiary i troski o powołania misyjne.

Zadania katechezy w polskim dyrektorium katechetycznym konsekwentnie podążają ścieżką wytyczoną przez DOK. Zgodnie z oczekiwaniami autorów PDK, są brane pod uwagę w określaniu celów szczegółowych i konstruowaniu programów katechetycznych ${ }^{57}$. Już bowiem Podstawa programowa katechezy Kościoła katolickiego z 2001 roku ujmowała całość zagadnień przewidzianych na konkretny etap edukacyjny w kluczu zadań katechezy wynikających z DOK. Do poszczególnych zadań były przypisane cele katechetyczne, $\mathrm{w}$ ich zakresie - zadania nauki religii i konkretne treści. Gdy w 2010 roku nastąpiła modyfikacja wspomnianej Podstawy programowej..., to właśnie zadania katechezy pozostały w układzie tabelarycznym jedyną niezmienioną kategorią. W pozostałych kolumnach znajdowały się zadania nauczyciela religii oraz treści - wymagania szczegółowe, odnośnie do których podano konkretne wiadomości oraz możliwe do zweryfikowania oczekiwania wobec ucznia. Cele katechetyczne równoznaczne z wymaganiami ogólnymi, czyli ogólnie sformułowane efekty kształcenia religijnego na danym etapie edukacyjnym, poprzedzały tabelaryczne ujęcie założeń programowych. Zbliżona terminologia została użyta w najnowszej podstawie programowej - zamiast zadań nauczyciela religii

55 PDK 29.

56 PDK 29.

57 Zob. PDK 30. 
pojawiły się treści odnoszące się do poszczególnych zadań katechezy, zaś do katalogu wymagań szczegółowych w zakresie wiadomości i oczekiwanych umiejętności dodano postawy. Postawy nie podlegają ocenie, a ich występowanie w tabeli wynika z ich związku z poszczególnymi zadaniami katechezy. Nowością wspomnianego dokumentu programowego z 2018 roku są kody występujące przy poszczególnych zadaniach, treściach oraz wymaganiach w zakresie wiedzy i umiejętności oraz postaw. Kolejnym zadaniom katechezy odpowiadają kolejne litery alfabetu od A do F, gdzie A odnosi się do rozwijania poznania wiary, zaś F do wprowadzenia do misji. Ułożenie treści programowych w kluczu zadań katechezy gwarantuje odniesienie do wszystkich wymiarów życia chrześcijańskiego.

\section{Dyrektorium o katechizacji}

Początek września 2020 roku pod względem katechetycznym obfitował w nowości. W szkołach - w wybranych klasach - zaczęła obowiązywać nowa Podstawa programowa katechezy Kościoła katolickiego w Polsce ${ }^{58}$. Inną nowością była prezentacja polskiego wydania Dyrektorium o katechizacji w Sekretariacie Konferencji Episkopatu Polski (3.09.2021) ${ }^{59}$. Dokument ten, autorstwa Papieskiej Rady ds. Krzewienia Nowej Ewangelizacji został zatwierdzony 23 marca, a ogłoszony w Watykanie 25 czerwca 2020 roku. Już w uzasadnieniu zredagowania nowego dyrektorium pojawiło się stwierdzenie, iż dyrektoria katechetyczne były ogłaszane w konsekwencji publikacji ważnych dokumentów - Ogólna instrukcja katechetyczna była pokłosiem nauczania II Soboru Watykańskiego, Dyrektorium ogólne o katechizacji ukazało się 5 lat po promulgowaniu Katechizmu Kościoła Katolickiego, zaś najnowsze Dyrektorium o katechizacji opublikowano w związku z Synodem poświęconym nowej ewangelizacji i adhortacji apostolskiej papieża Franciszka Evangelii gaudium. Pomijając kwestię porównywalności wskazanych wydarzeń, warto zauważyć, iż zgodnie z zawartą we wstępie dokumentu deklaracją R. Fisichelli, „Dyrektorium o katechizacji stanowi kolejne, dynamiczne rozwinięcie dwóch wcześniejszych tekstów, z którymi zachowuje ciągłość" ${ }^{60}$. Dalej Przewodniczący Papieskiej Rady ds. Krzewienia Nowej Ewangelizacji stwierdza, iż „te trzy teksty [DCG, DOK i DK] łączy to, że wszystkie upominają się o te same cele

\footnotetext{
58 Od 1 września podręczniki zgodne z nową podstawą programową mogły być stosowane w oddziałach przedszkolnych oraz w klasach 1 i 5 szkoły podstawowej, obligatoryjne zaś stały się dla klas pierwszych szkół ponadpodstawowych. Zob. Uchwała Komisji Wychowania Katolickiego Konferencji Episkopatu Polski z dnia 19 września 2018 roku w sprawie obowiązywania „Podstawy programowej katechezy Kościoła katolickiego w Polsce" i programów nauczania religii oraz oceny podręczników wraz ze zmianami wprowadzonymi w dniu 5 grudnia 2018 roku - tekst jednolity, https://opoka.org. pl/biblioteka/W/WE/komisje/kwk/uchwala20180918.html [20.09.2021].

59 https://www.ekai.pl/prezentacja-watykanskiego-dyrektorium-o-katechizacji [20.09.2021].

60 DK, Wstęp, s. 7.
} 
i zadania dla katechezy" ${ }^{61}$. Stwierdzenie to może zaskakiwać choćby z tego względu, iż liczba zadań katechezy względem poprzednich dyrektoriów została zredukowana do pięciu. Nowy dokument zadaniom katechezy poświęca numery 79-89, a same zadania brzmią następująco: prowadzić do poznania wiary (80), wtajemniczyć w sprawowanie Misterium (81-82), formować do życia w Chrystusie (83-85), uczyć modlitwy (86-87) i wprowadzać do życia wspólnotowego (88-89). Nazwy wszystkich pięciu zadań są na tyle zbliżone do tych znanych z DOK, że można zastanawiać się, co było motywem zmiany ich brzmienia? Niewątpliwie zaś zadania odnoszą się do różnych wymiarów życia, co łączy je z poprzednimi dyrektoriami.

W odniesieniu do pierwszego z zadań - prowadzić do poznania wiary - podkreśla się, iż katecheza ma ułatwiać poznanie i zgłębianie orędzia. Wymiar poznawczy jest tam wyraźnie akcentowany, a wręcz przestrzega się przed przeciwstawianiem treści doświadczeniu wiary, podobnie jak papież Jan Paweł II przestrzegał przed przeciwstawianiem sposobu życia nauce ${ }^{62}$. W katechezie potrzeba zarówno treści, jak i doświadczenia wiary.

Drugiemu zadaniu - wtajemniczyć w sprawowanie Misterium - nadano wyraźny charakter inicjacyjny. Świadomy udział w liturgii, do którego przygotowuje katecheza, ułatwia poznanie tajemnicy Chrystusa i ściśle z Nim jednoczy. Ważną kwestią, którą podniesiono w nowym Dyrektorium w kontekście tego zadania jest uczenie rozumienia roku liturgicznego oraz niedzieli. Rok liturgiczny zyskał nawet miano „prawdziwego nauczyciela wiary”. Nie zmienia to jednak faktu, iż świadome i aktywne uczestnictwo w liturgii domaga się poprzedzającej je katechezy, w ramach której nastąpi kształtowanie postaw - radości, poczucia wspólnotowości, słuchania słowa Bożego, ufnej modlitwy, uwielbienia i dziękczynienia, wrażliwości na symbole i znaki ${ }^{63}$. Postuluje się również dowartościowanie ludowej pobożności, która stanowi formę wyrażenia wiary.

W kolejnym zadaniu - formować do życia w Chrystusie - pobrzmiewają echa poprzednich dyrektoriów, bowiem kluczowe idee związane $\mathrm{z}$ formacją moralną koncentrują się wokół Błogosławieństw i idei naśladowania Jezusa oraz kształtowania sumienia. Zadanie to jest również rozpatrywane w perspektywie powołania zarówno wezwania do świętości, jak i życiowego powołania, na którego drodze nie można zagubić swej godności chrześcijańskiej. W ramach katechezy należy więc ukazywać możliwości przekładania wiary na życie i postępowania pełnego

61 Tamże, s. 9.

${ }^{62}$ Zob. CT 22. Kontynuując tę myśl papież surowo zabronił: „Niech się nikt nie odważy przeciwstawiać katechezy wychodzącej od życia, katechezie tradycyjnej, która jest doktrynalna i ma swoje określone drogi i strukturę. Prawdziwa katecheza jest zawsze uporządkowanym i systematycznym wprowadzeniem w Objawienie, które sam Bóg dał o sobie w Jezusie Chrystusie, zachowane w głębokiej pamięci Kościoła i w Piśmie świętym i stale przekazywane przez żywą i czynną tradycję z pokolenia na pokolenie. Objawienie to nie jest jednak ani oderwane od życia, ani mu jak gdyby sztucznie przeciwstawiane". Tamże.

63 Zob. DK 82. 
miłości, której wzorem jest Jezus Chrystus. Tak prowadzona formacja moralna z jednej strony przyczyni się do budowania Królestwa Bożego na ziemi, z drugiej zaś pozwoli z nadzieją oczekiwać wiecznego szczęścia w niebie ${ }^{64}$.

Również zadanie - uczyć modlitwy - nawiązuje do tożsamego zadania w poprzednim dyrektorium - połowę numeru 86. stanowi cytat z DOK wyjaśniający, co to znaczy modlić się z Jezusem. Nowością jest ukazanie modlitwy jako daru, zaś nie do końca zrozumiałe jest stwierdzenie, iż „katecheza ma za zadanie uczyć modlitwy i w modlitwie" ${ }^{65}$. Być może owo uczenie w modlitwie jest jedynie ozdobnym zwrotem lub mało trafnym wyrażeniem prawdy, iż czas modlitwy również może być kształcący. W kolejnym numerze znalazły się konkretne wytyczne zarówno w zakresie nauczania modlitwy osobistej, jak i liturgicznej i wspólnotowej.

Ostatnie zadanie - wprowadzać do życia wspólnotowego - wynika ze wspólnotowego charakteru wiary. Przynależność do Kościoła zobowiązuje do współodczuwania $z$ innymi - również będącymi członkami tej samej wspólnoty. Pamiętając o tym, znacznie łatwiej dostrzegać w innych to, co pozytywne, a jednocześnie wyzbywać się wszystkiego, co zagraża przyjaznemu traktowaniu bliźnich. W zakresie omawianego zadania katecheza ma następujące zobowiązania: rozwijać poczucie przynależności do Kościoła, uczyć poczucia jedności w Kościele i formować do poczucia współodpowiedzialności za Kościół.

W ostatnim zdaniu numeru 89. doprecyzowano, iż owo formowanie do poczucia współodpowiedzialności za Kościół ma służyć temu, by „jego członkowie aktywnie uczestniczyli w budowaniu wspólnoty i jako uczniowie-misjonarze przyczyniali się do jego rozwoju" ". . Mimo tej troski o rozwój wspólnoty Kościoła i przypomnieniu konieczności stawania się uczniami-misjonarzami, w nowym Dyrektorium o katechizacji nie pozostawiono dotychczasowego zadania misyjnego, które wprawdzie i w latach 90., gdy pojawiło się w DOK, to było szeroko rozumiane - w znaczeniu misji chrześcijan w świecie oraz działalności misyjnej ad gentes, w tym również do dialogu z innymi religiami niechrześcijańskimi. Niektórzy twierdzą, iż dotychczasowe zadanie katechezy wg DOK - wprowadzenie do misji, w nowym Dyrektorium stało się celem ${ }^{67}$. Istotnie, nowe Dyrektorium wielokrotnie posługuje się pojęciem misji i misyjności - katecheza a misja, nawrócenie misyjne, uczniowie-misjonarze, katecheza, która wychodzi na misje, permanentny stan misji, perspektywa misyjna - indeks tematyczny wskazuje na 51 odniesień do hasła misja (misyjny, posłannictwo) w treści dokumentu. Ani jedno hasło jednak nie odnosi się do misji w liczbie mnogiej, utożsamianych do tej pory z działalnością misyjną ad gentes. Również postulat stawania się uczniami-misjonarzami wprowadza pewien chaos

\footnotetext{
${ }^{64}$ Zob. DK 83-85.

${ }^{65}$ DK 86.

66 DK 89.

${ }^{67}$ Zob. Re-Imagining the Tasks for Catechesis: A Road Map for Missionary Discipleship, https:// iceont.ca/wp-content/uploads/2021/04/MG_Reimagining-Tasks-Spring2021.pdf [20.10.2021], s. 3.
} 
terminologiczny, bowiem w tym zwrocie misjonarzami nie są „wysłani przez Kościół głosiciele Ewangelii, [którzy] idąc na cały świat, podejmują celem wykonania zadań głoszenia Ewangelii i zakładania Kościoła wśród narodów lub grup społecznych jeszcze nie wierzących w Chrystusa" ${ }^{68}$.

\section{Podsumowanie}

Choć II Sobór Watykański nie wydał osobnego dokumentu katechetycznego, to wyraził potrzebę jego opracowania i zapowiedział „poradnik katechetycznego nauczania ludu chrześcijańskiego, w którym byłaby mowa o podstawowych zasadach tegoż nauczania, jego organizacji oraz opracowaniu książek dotyczących tego przedmiotu"69. Na przestrzeni minionych pięćdziesięciu lat wydano aż trzy takie podręczniki dla całego Kościoła. W każdym z nich wśród treści fundamentalnych dla katechetycznej posługi słowa znalazły się zadania katechezy. Trudno nie dostrzec rozwoju ich koncepcji od 1971 do 1997 roku. Po ogłoszeniu Ogólnej instrukcji katechetycznej zadania katechezy w liczbie i brzmieniu zaproponowanych przez autorów dokumentu nie przeniknęły do świadomości zarówno katechetów, jak

${ }^{68}$ DM 6. W nowym Dyrektorium o katechizacji ów chaos pojęciowy czy też brak precyzji dotyczą nie tylko misji, ale także pojęcia ewangelizacji, które nazbyt często utożsamiane jest $\mathrm{z}$ nową ewangelizacją. Być może przyczynił się do tego fakt, iż dokument przygotowała Papieska Rada ds. Krzewienia Nowej Ewangelizacji, której papież Benedykt XVI powierzył kompetencje dotychczas posiadane przez inne dykasterie, takie jak Kongregację ds. Duchowieństwa czy Międzynarodową Radę ds. Katechezy. Trudno nie odnieść wrażenia, iż owa Rada z racji swej nazwy suponuje rozumienie ewangelizacji w nieco zawężonej perspektywie. Wybrzmiewa to nawet w nawiązaniu do wspomnianego przeniesienia kompetencji poprzez stwierdzenie: „Benedykt XVI wielokrotnie podkreślał znaczenie katechezy w procesie nowej ewangelizacji, a swoim listem apostolskim Fides per doctrinam (2013) w sposób konkretny urzeczywistniał to zadanie" (DK 6). Tymczasem we wspomnianym liście za każdym razem jest mowa o katechezie w procesie ewangelizacji. „Blessed John Paul II, concluding the Synod of Bishops devoted to catechesis, also wrote that "within the whole process of evangelization, the aim of catechesis is to be the teaching and maturation stage”; „We cannot forget other significant moments in defining the nature, method and ends of catechesis in the process of evangelization”; "The teaching of the Council and the subsequent magisterium, reflecting the Church's great tradition in this regard, closely linked catechesis to the process of evangelization”; „Taking all these things into account, I consider it right that this same Dicastery should assume as one of its institutional duties the task of vigilance, to be exercised in the name of the Supreme Pontiff, over that instrument of evangelization which is the Church's catechesis". Benedykt XVI, List apostolski Fides per doctrinam, https://www.vatican.va/content/benedict-xvi/en/motu_proprio/documents/ hf_ben-xvi_motu-proprio_20130116_fides-per-doctrinam.html [28.09.2021]. Ich wzajemne relacje faktycznie wybrzmiewały do tej pory za każdym razem w kluczowych dokumentach katechetycznych - mowa więc była o ewangelizacji w znaczeniu szerokim. Tymczasem ograniczenie refleksji do nowej ewangelizacji, jakie można odnieść wrażenie ma miejsce w Dyrektorium o katechizacji, przyćmiewa nieco różne formy działalności wewnątrz jednej misji Kościoła.

${ }^{69} \mathrm{ChD} 44$. 
i odpowiedzialnych za organizację katechezy. Diametralnie inaczej potoczyła się analogiczna kwestia w Dyrektorium ogólnym o katechizacji - od 1997 roku „sześć zadań katechezy wynikających z DOK" na dobre zagościło w refleksji i praktyce katechetycznej. Przeniknęło także do Dyrektorium katechetycznego Kościoła katolickiego $w$ Polsce, gdzie zadania te nabrały specyficznego kształtu uwarunkowanego kontekstem lokalnym i możliwościami ich realizacji w ramach poszczególnych form katechezy. Stamtąd zaś trafiły do katechetycznych dokumentów programowych, a przez nie do podręczników i na lekcje religii, gdzie odbywała się ich realizacja. W tę swoistą ciągłość refleksji nad zadaniami katechezy w pewien sposób wpisuje się Dyrektorium o katechizacji z 2020 roku - nawet jeśli lekko zmienione ich brzmienie miałoby sugerować coś innego. Co do samego rozumienia zadań katechezy w nowym Dyrektorium, to nie różni się ono zbyt mocno od tego, które prezentowano w dokumencie z lat 90. Niewątpliwie próbowano je nieco zaktualizować, jednak bardziej od strony formy niż treści, choćby wplatając w niektóre z nich nauczanie papieża Franciszka. Budzi niepokój zredukowanie zadań do pięciu, przez pominięcie wprowadzenia do misji, zwłaszcza w kontekście adaptacji dokumentu do warunków polskich. Jeśli bowiem autorzy chcieliby przyjąć schemat zadań katechezy z DK, to czy nie wprowadzi to konieczności modyfikacji dokumentów programowych, które ledwie zaczęły obowiązywać? Szczególnie, iż wprowadzenie do misji w polskiej katechezie znacząco rozwinęło się w ostatnich latach, co widać zarówno w formacji katechetów, podręcznikach do religii, a także zaangażowaniu w rozmaite akcje i konkursy o tematyce misyjnej. Niektóre diecezje i środowiska katechetyczne ożywiły zapał misyjny jeszcze przed Nadzwyczajnym Miesiącem Misyjnym (październik 2019) i wciąż rozpalają nim szkoły i parafie.

Katecheza „oświeca i wzmacnia wiarę, karmi życie wedle ducha Chrystusowego, doprowadza do świadomego i czynnego uczestniczenia w misterium liturgicznym i pobudza do działalności apostolskiej" ${ }^{\prime 70}$. Jej zadania w ten sposób zarysowane w deklaracji Gravissimum educationis pozostają aktualne, bowiem odzwierciedlają wszystkie wymiary życia chrześcijańskiego. Należy przygotować katechizowanych do przeżywania każdego z nich w sposób właściwy uczniom Jezusa. Z tego też wypływa doniosłość zadań katechezy - nie tyle są one opisem na użytek refleksji naukowej, ile „tym, co należy wykonać” w pracy katechetycznej głównymi kierunkami działania, których efektywność przynajmniej w pewnym zakresie będzie możliwa do weryfikacji (zwłaszcza w warunkach szkolnych). Z tego względu ich omówienie w dokumencie katechetycznym powinno być możliwie trwałe. Są dla katechezy niczym drogowskazy, które nawet jeśli będą odnawiane, to wciąż powinny wskazywać na to samo miejsce docelowe.

Słowa kluczowe: zadania katechezy, dyrektoria katechetyczne, programowanie katechezy, dokumenty katechetyczne.

${ }^{70}$ GE 4. 


\section{Summary}

The article presents the development of catechetical thought on the tasks of catechesis in general catechetical directorates from 1971, 1997 and 2020 and the Polish catechetical directorate from 2001. After discussing the number of tasks and their understanding in each document, the mutual relations between individual directors were indicated, as well as reflection on the tasks of catechesis undertaken over the last 50 years. The relationship between the tasks of catechesis and catechetical practice was also indicated, as well as the challenges in the discussed topic that the authors of the national directory will face.

Keywords: catechesis tasks, catechetical director, catechetical programming, catechetical documents.

\section{Riassunto}

Nell'articolo è stato presentato lo sviluppo del pensiero catechistico sui compiti della catechesi nei direttori generali della catechesi del 1971, 1997 e 2020, come pure nel direttorio della catechesi polacca del 2001. Dopo la riflessione sul numero dei compiti e sulla loro comprensione in ciascun documento, sono stati indicati i rapporti reciproci tra i singoli direttori, nonché la valutazione dei compiti della catechesi intrapresi negli ultimi 50 anni. Inoltre, si è focalizzati sul rapporto tra i compiti della catechesi e la pratica catechetica, nonché sulle sfide nell'ambito discusso che gli autori del Direttorio nazionale dovranno affrontare.

Parole chiavi: compiti della catechesi, repertorio catechetico, programmazione catechetica, documenti catechetici

\section{Bibliografia}

Alberich E., Cele katechezy, w: Stownik katechetyczny, Gevaert J., Misiaszek K. (red.), Warszawa 2007, s. 128-131.

Benedykt XVI, List apostolski Fides per doctrinam, https://www.vatican.va/content/benedict-xvi/en/motu_proprio/documents/hf_ben-xvi_motu-proprio_20130116_fides-per-doctrinam.html [28.09.2021].

Blachnicki F., Katechetyka fundamentalna, Lublin 1970, s. 81.

Chałupniak R., Katechetyka fundamentalna, w: Chałupniak R., Kostorz J., Wybrane zagadnienia $z$ katechetyki, Opole 2002, s. 15-58.

Charytański J., Biuletyn katechetyczny, „Collectanea Theologica” 3(1972), s. 137-174.

Charytański J., Inspiracje soborowe w katechetyce, w: Kubik W. (red.), Katecheza po Soborze Watykańskim II, Warszawa 1985, t. 1, s. 13-44.

Charytański J., Katecheza wświetle Ogólnej instrukcji katechetycznej (Directorium catechisticum generale), w: Kubik W. (red.), Katecheza po Soborze Watykańskim II, Warszawa 1985 , t. 1, s. $45-52$.

Charytański J., Z Dobra Nowina w szkole, Warszawa 1991.

Dziekoński S., Zadania współczesnej katechezy w dokumentach katechetycznych Kościoła $w$ Polsce, w: Dziekoński S. (red.), Przesłanie dokumentów katechetycznych Kościoła $w$ Polsce, Warszawa 2003, s. 103-122. 
https://www.ekai.pl/prezentacja-watykanskiego-dyrektorium-o-katechizacji/ [20.09.2021]. II Sobór Watykański, Deklaracja o wychowaniu chrześcijańskim Gravissimum educationis, Rzym 1965, wyd. polskie, w: II Sobór Watykański, Konstytucje, dekrety, deklaracje, Poznań 2002, s. 314-324.

II Sobór Watykański, Dekret o pasterskich zadaniach biskupów w Kościele Christus Dominus, Rzym 1965, wyd. polskie, w: II Sobór Watykański, Konstytucje, dekrety, deklaracje, Poznań 2002, s. 236-258.

Jabłońska B., Szczególne zadania katechezy, „Katecheta” 3(1973), s. 110-112.

Jan Paweł II, Adhortacja apostolska Catechesi tradendae.

Kamecki F., Ważniejsze zadania katechetyczne, „Katecheta” 4(1982), s. 145-151;

Komisja Wychowania Katolickiego KEP, Uchwała Komisji Wychowania Katolickiego Konferencji Episkopatu Polski z dnia 19 września 2018 roku w sprawie obowiązywania „Podstawy programowej katechezy Kościoła katolickiego w Polsce” i programów nauczania religii oraz oceny podręczników wraz ze zmianami wprowadzonymi $w$ dniu 5 grudnia 2018 roku - tekst jednolity, https://opoka.org.pl/biblioteka/W/WE/komisje/ kwk/uchwala20180918.html [20.09.2021].

Komisja Wychowania Katolickiego, Dyrektorium katechetyczne Kościoła katolickiego w Polsce, Kraków 2001.

Kongregacja ds. Duchowieństwa, Dyrektorium ogólne o katechizacji, Rzym 1997, wyd. polskie Poznań 1998.

Kongregacja ds. Duchowieństwa, Ogólna instrukcja katechetyczna, Rzym 1971, wyd. polskie Warszawa 1981.

Łuczak H., Katecheta wobec zadań katechezy w Polsce, „Katecheta” 6(1981), s. 263-265.

Marek Z., Zbawcze orędzie w posłudze katechetycznej, w: Katecheza w świetle Dyrektorium ogólnego o katechizacji, Kraków 1999, s. 93-121.

Papieska Rada ds. Krzewienia Nowej Ewangelizacji, Dyrektorium o katechizacji, Rzym 2020, wyd. polskie Kielce 2020.

Re-Imagining the Tasks for Catechesis: A Road Map for Missionary Discipleship, https:// iceont.ca/wp-content/uploads/2021/04/MG_Reimagining-Tasks-Spring2021.pdf [20.10.2021].

Słownik języka polskiego, https://sjp.pwn.pl/sjp/zadanie;2542078.html [18.08.2021].

Zima B. S., Zadania katechezy, „Katecheta” 3(1976), s. 127-129.

\section{O autorze}

Aneta RAYZACHER-MAJEWSKA - dr teologii w zakresie katechetyki, adiunkt w Katedrze Katechetyki Fundamentalnej i Materialnej na Wydziale Teologicznym Uniwersytetu Kardynała Stefana Wyszyńskiego w Warszawie, konsultor Komisji Wychowania Katolickiego Konferencji Episkopatu Polski, rzeczoznawca ds. oceny programów nauczania religii i podręczników katechetycznych, przewodnicząca Komisji Rewizyjnej Stowarzyszenia Katechetyków Polskich, katechetka w przedszkolach, autorka materiałów katechetycznych, kierownik projektów „Katecheta - człowiek z klasą” i „Katecheza bez granic”. 